\title{
A magyarországi kiskereskedők és vállalatok fizetési szokásainak elemzése*
}

\author{
Deák Vivien - Kajdi László - Nemecskó István
}

Tanulmányunkban a magyarországi kiskereskedők és vállalatok fizetési szokásait, azon belül föként az elektronikus fizetések elfogadását és arányát vizsgáljuk a 2019-es tárgyidőszakban. Ehhez két kérdőives felmérés és az online pénztárgépek adatbázisának adatait elemezzük statisztikai módszerek, döntési fák és regressziók segítségével. Eredményeink alapján a kiskereskedők pénzforgalma jellemzően készpénzintenzív, míg a vállalatoknál az átutalásos tranzakciók vannak túlsúlyban. A kártyaelfogadást és az elfogadóhelyek esetében a készpénzarányt leginkább befolyásoló tényezők a kiskereskedőknél az árbevétel, illetve a vásárlás értéke, míg a vállalatoknál a készpénzes bérfizetés aránya. A költség is fontos szerepet játszik a kártyaelfogadás tekintetében, így az olcsóbb elektronikus fizetési megoldásokat biztositó azonnali fizetés fontos lehet a kisebb kereskedők, vállalatok esetében az elektronikus fizetés biztosításánál. Közpolitikai intézkedésekkel elsősorban a kiskereskedök és a mikro-és kisvállalkozások szegmensét lehetne célozni.

Journal of Economic Literature (JEL) kódok: G20, D12, R11

Kulcsszavak: pénzforgalom, kártyaelfogadás, kkv, kiskereskedők

\section{Bevezetés}

A Magyar Nemzeti Bank (MNB) folyamatosan vizsgálja a különböző gazdasági szereplők fizetési szokásait, azon belül is különös figyelemmel az elektronikus fizetések használatának lehetőségét és mértékét. Ez az általános pénzforgalmi ismeret bővítésén kívül azért is fontos, mert, ahogy Bartha et al. $(2017,310$. o.) is bemutatta különböző elemzések, eredmények összefoglalásával, hogy az elektronikus fizetések elterjedése pozitív hatással van a gazdaságra, a hatékonyabb pénzforgalmi rendszer kedvezően hat a gazdaság versenyképességére és növekedésére, illetve a társadalmi szinten olcsóbban múködő pénzforgalom is pozitívan hat a gazdaságra az erőforrások felszabadításán, a vállalatok hatékonyságának javításán és a feketegazdaság visszaszorításán keresztül. Az MNB rendszeresen végez kérdőíves adatfelvételeket

\footnotetext{
* A jelen kiadványban megjelenő írások a szerzők nézeteit tartalmazzák, ami nem feltétlenül egyezik a Magyar Nemzeti Bank hivatalos álláspontjával.
}

Deák Vivien a Magyar Nemzeti Bank elemzője. E-mail: deakv@mnb.hu

Kajdi László a Magyar Nemzeti Bank vezető közgazdasági elemzője. E-mail: kajdil@mnb.hu

Nemecskó István a Magyar Nemzeti Bank elemzője. E-mail: nemecskoi@mnb.hu

A magyar nyelvű kézirat első változata 2021. március 11-én érkezett szerkesztőségünkbe.

DOI: http://doi.org/10.25201/HSZ.20.2.3359 
a hazai fizetési szokásokról, a lakosságra és a vállalati szférára vonatkozóan. E felmérések előnye, hogy míg a sok esetben teljes körű adminisztratív és banki adatszolgáltatások révén nagy pontossággal lehet követni a főbb pénzforgalmi trendeket, a részletesebb adatbázisokból (mint például az online pénztárgépek adatbázisából) kinyerhető információk és a további többletinformációkat tartalmazó kérdőíves adatfelvételek lehetővé teszik a mögöttes oksági kapcsolatok feltárását is. Állami és jegybanki szempontból ez azért különösen lényeges, mert nagyban hozzájárulhat ahhoz, hogy hatékony, az elektronikus fizetések elterjedését elősegítő közpolitikai intézkedések szülessenek.

A közelmúltban is számos olyan közpolitikai lépés történt, amely jelentős mértékben befolyásolta a hazai fizetési piacot, azon belül is a vállalati-kiskereskedelmi szegmenst. Elegendő csak az állami POS-terminál-telepítési programokra vagy az online pénztárgépek széleskörü bevezetésére gondolni. Mindezek okán időszerű volt, hogy a korábbi, hasonló jellegű kérdőíves vizsgálatok után az MNB ismételten felmérje a magyar vállalkozások és kiskereskedők fizetési szokásait. Emellett előfordulnak olyan kérdések, például a kártyaelfogadást befolyásoló tényezők, ahol a kiskereskedelmi tranzakciókat nagymértékben lefedő, részletes onlinepénztárgép-adatokon végzett elemzések a kiskereskedelmi szektor robusztusabb és kérdőíves felméréssel nem felmérhető tényezők szerinti vizsgálatát teszik lehetővé. Tanulmányunkban ezt az adatbázist is felhasználjuk, kiegészítve ily módon a részben eltérő információkat tartalmazó kérdőíves felmérésen végzett elemzéseket.

Jelen tanulmányunkban az alábbi főbb kutatási kérdéseket kívánjuk részletesebben vizsgálni, majd abból a gyakorlatot is érintő közpolitikai jellegű következtetéseket levonni: 1) Mi jellemzi a hazai vállalkozások és kiskereskedők fizetési szokásait, vannak-e eltérések a két csoport között, illetve a korábbi, hasonló adatfelvételekhez képest? 2) Mi jellemzi a két vizsgált célsokaság pénzügyi tudatosságát, ismereteit az azonnali fizetésről, pénzforgalmi (banki) költségeit, azonosíthatók-e olyan részcsoportok, amelyek jelentősen drágábban vehetik igénybe az elektronikus fizetési megoldásokat? 3) Mi jellemzi a hazai kártyaelfogadói hálózatot, milyen tényezők befolyásolják a kártyaelfogadás biztosítását és a készpénzhasználatot? Az adatok vizsgálata során alapvető statisztikai összefüggések mellett a kártyaelfogadást és a készpénzes fizetéseket befolyásoló tényezőket döntési fa és regressziók segítségével is elemezzük, hogy minél pontosabban tudjuk azonosítani a fó befolyásoló tényezőket. A második fejezetben ismertetjük az eddigi szakirodalmak eredményeit, a harmadik fejezetben az adatokat és a felhasznált módszertant. Az adatok alapján a negyedik és ötödik fejezetben mutatjuk be az elfogadói hálózat fejlettségét és a forgalmi adatokat. A hatodik fejezetben a fizetési módok közötti választást befolyásoló pénzügyi tudatosságra vonatkozó kérdéseket összesítjük. Végül, a hetedik fejezetben összegezzük az eredményeket és levonjuk a következtetéseket. 


\section{Szakirodalmi áttekintés}

Számos tanulmány született már a fizetési szokások témájában, azonban ezek jelentős része a fogyasztói döntéseket vizsgálja, így jelen elemzés szempontjából csak a kiskereskedői szegmensre vonatkoztathatók ezek az eredmények korlátozott mértékben. Lengyel felmérések azt mutatják, hogy bár a fogyasztók jellemzően ismerik az elektronikus fizetési módokat, a fogyasztói szokások mégis csak lassan és az adott fizetési módhoz kapcsolódó előnyökkel változtathatók meg (Harasim - Klimontowicz 2013; Dahlberg - Öörni 2008). Mindez nehezíti az elektronikus fizetési módok elfogadásának elterjedését, mivel a várható alacsony forgalom miatt a kereskedők gyakran elutasítóak ezen új fizetési lehetőségek bevezetésével szemben. Egy holland fogyasztói vizsgálat (Jonker et al. 2018) azt mutatta, hogy a készpénzes tranzakciók átcsatornázódása a kártyás fizetési módra nagyban függ a fogyasztók jövedelmétól, a vásárlás értékétől, valamint nagyobb mértékű a nem kiskereskedelmi főtevékenységű vállalkozások körében.

Számos országban a fogyasztói felmérések mellett kifejezetten a vállalkozásokra vonatkozó vizsgálatokat is végeztek. Leinonen (2008) finn vállalatokra és kiskereskedőkre irányuló elemzései azt mutatták, hogy a vállalatok esetében jóval meghaladta az elektronikus fizetési módok használata a készpénzét, és a válaszadók további erősödést vártak ezen a téren. Érdekes eredmény az is, hogy ebben a szegmensben az elektronikus fizetési módok használatát nagyban befolyásolja, hogy a pénzforgalmi szolgáltatók milyen benyújtási csatornákat biztosítanak vállalati ügyfeleiknek, illetve hogyan lehet ezeket integrálni a számlázási és könyvelési rendszerekbe. A kiskereskedők esetében ugyanakkor a legfontosabb szempont a pénzügyi tranzakciók gyors (valós idejű) és minél egyszerúbb lebonyolítása. Mindez megmagyarázza, hogy ebben a szegmensben miért olyan jelentős a készpénzhasználat, ugyanakkor lényeges, hogy a felmérés óta számos szabályozási lépés történt a kártyapiacon a verseny növelése érdekében, és már elérhetők azonnali fizetési megoldások is. Gresvik és Haare (2007) a fizikai elfogadóhelyeken lebonyolított tranzakciókat vizsgálta. Eredményeik szerint a skandináv államokban már bő egy évtizeddel ezelött is 50 százalék alá csökkent a készpénzes tranzakciók aránya, a legújabb, dán vállalatok közötti (B2B) fizetésekre vonatkozó felmérésben pedig már meg sem jelenítették a készpénzes tranzakciókat, annyira elhanyagolhatónak ítélték használatukat (The Danish Payments Council 2019). Más, a készpénzt intenzívebben használó országokban a kártyaelfogadás jellemzően a kereskedő cég méretével függ össze, azaz a nagyobb kereskedelmi cégek esetében jóval gyakoribb - mutat rá egy, a kanadai kiskereskedők körében végzett felmérés (Kosse et al. 2017). Hasonló eredményre jutott Looke (2007) a maláj piacot vizsgálva, ahol kereskedői oldalon a forgalom nagysága mellett a kereskedelmi szegmens is meghatározó a kártyaelfogadásról szóló döntésnél. Bounie et al. (2017) kiskereskedői és lakossági felmérések összevetésével a francia piacot vizsgálta, és elsősorban a hálózati hatásokat hangsúlyozva 
arra jutott, hogy a kártyaelfogadást nagyban befolyásolja a fogyasztói preferencia a fizetési módok között, azaz hogy a vásárlók oldalán mekkora igény mutatkozik a kártyás fizetésre.

A hazai viszonyokat Turján et al. (2011) elsősorban a fizetési módokhoz kapcsolódó költségek szempontjából vizsgálta, míg Takács (2011) és Ilyés - Varga (2015) a lakossági szegmensben elemezte a fizetési szokásokat, jelentős dominanciát kimutatva a készpénzhasználat tekintetében. Ilyés - Varga (2018) a kiskereskedők kártyaelfogadására fókuszálva a Nemzeti Adó- és Vámhivatal (NAV) onlinepénztárgép-adatbázisa alapján jelentős készpénz-dominanciát mutatott ki a kiskereskedői pénzforgalomban, és megállapította, hogy a 2016-os adatok alapján az üzletméret tekinthető a kártyaelfogadási hajlandóság legfontosabb magyarázó változójának. A korábbi elemzések továbbá azt is megerősítették, hogy jelentős területi eltérések is tapasztalhatók a kiskereskedői kártyaelfogadás terén, ami kevésbé fejlett a keleti országrészben és a kisebb településeken (Kajdi - Nemecskó 2020). Kvalitatív és kvantitatív módszereket egyaránt alkalmazó vizsgálatában Bódi-Schubert (2014) kifejezetten a kis- és középvállalkozásokat célozta. Az elemzés azt mutatta, hogy bár a vállalatok közötti tranzakcióknál egyértelműen az átutalás tekinthető a meghatározó fizetési módnak, mégis gyakori a készpénzhasználat, amelyet elsősorban a bizalomhiánnyal, a lánctartozások elkerülése miatt indokoltak a válaszadók. A későbbi, mikrovállalkozásokat is fókuszba helyező felmérés (Belházyné et al. 2018) hasonló eredményekre jutott a fizetési módok megoszlásával kapcsolatban, a készpénzhasználat okaként azonban már kevésbé a bizalomhiányt és sokkal inkább az egyes partnerek között kialakult szokásokat jelöli meg. Ez a tanulmány is megerősíti továbbá, hogy a vállalatméret növekedésével csökken a készpénzhasználat.

\section{Adatok és módszertan}

A tanulmány megírásánál két kérdőíves felmérés adatait és a NAV által biztosított, az MNB rendelkezésére álló onlinepénztárgép-adatokat használtuk fel. Az MNB megbízásából a Kutatópont Kft. végzett kérdőíves felméréseket külön a kiskereskedelmi, illetve az egyéb tevékenységgel bíró vállalati szektor 2019-es tárgyévét leíró adatokra vonatkozóan 2019. december - 2020. január folyamán. Mindkét adatfelvétel sikeres (válaszokat adó) mintaelemszáma 300 vállalkozás volt. A vállalati mintában főleg szolgáltatók (gépjárműjavítással, ingatlanközvetítéssel, szállítmányozással foglalkozók), termeléssel foglalkozó vállalatok (bútor-, ruházatgyártás), illetve az építkezéssel és kivitelezéssel foglalkozó vállalkozások (út és lakóépület építése) szerepelnek. A vállalatokra vonatkozó adatok a nyilvánosan elérhető $\mathrm{KSH}$-adatok alapján régió, főtevékenység és létszám-kategóriák alapján kerültek súlyozásra és teljeskörűsítésre. 
A kérdőíves kiskereskedői adatbázis a kiskereskedelmi főtevékenységú vállalatokat tartalmazza, és ebben az esetben a NAV-tól átvett online pénztárgép (OPG) adatok is felhasználásra kerültek a súlyozásnál és teljeskörűsítésnél. Ez 50837 darab kiskereskedelmi főtevékenységű adózót jelentett, és ez alapján az adatok régió, forgalmi kategória, valamint a fötevékenység (47 TEÁOR csoport) szerint reprezentatívak. A kiskereskedői minta csak az 1 milliárd forintos éves bruttó árbevétel alatti kiskereskedőket vette figyelembe, az ennél nagyobb vállalatokat - jellemzően kiskereskedelmi láncokat - nem. A kérdőíves adatfelvételek során egyaránt lehetőség volt a személyes, telefonos, valamint online kitöltésre. Mivel részletes gazdálkodási, pénzügyi adatokat kellett nyújtani, ezért az összeírók jellemzően a vállalkozások kontrolling területeit keresték meg. A kérdések kiterjedtek a konkrét adatok (pl. beés kimenő pénzforgalom fizetési módok szerinti megoszlása, bankolási költségek, bérköltségek és bérfizetés módja, alkalmazotti létszám stb.) mellett attitűd jellegű kérdésekre is, ami elsősorban a pénzügyi tudatosság mérésére, valamint a jövőbeli fejlesztésekre vonatkozó tervek számbavételére alkalmazható.

A kérdőívek alacsony mintaelemszámából következően elemzésünk csak a főbb leíró adatok, megoszlások bemutatására szorítkozik, kiegészítve a fogyasztók általi készpénzhasználatot és a kártyaelfogadási szolgáltatást befolyásoló magyarázó változókat részletesebben vizsgáló elemzésekkel. A legfőbb magyarázó változók azonosítására a gépi tanuláson alapuló döntési fa módszert használtuk, emellett a statisztikai módszertanon alapuló, a magyarázó változók parciális hatását jobban leíró regressziókat is alkalmaztunk. A kártyaelfogadás vizsgálatánál a logisztikus, a készpénzhasználat vizsgálatánál pedig a kártyát elfogadó és nem elfogadó üzletek okozta szelekciós hatást is kezelő Heckman-féle szelekciós modellt alkalmaztuk.

A kérdőíves adatok mellett az online pénztárgépek kiskereskedelemre vonatkozó 2019. évi adatait is megvizsgáltuk ugyanazon módszerekkel a kiskereskedelmi kérdőíveken végzett elemzések eredményeinek ellenőrzése, illetve újabb vizsgálati szempontokkal való kiegészítése céljából, a kiskereskedelmi láncokra jellemző 1 milliárd forint feletti éves bevétellel rendelkező adózók adatait leszúrve. A nagy mintaelemszám miatt az OPG-adatbázison végzett elemzések robusztusabbak, mivel tartalmazzák az online pénztárgép használatára kötelezett kereskedők összes nyugta, illetve egyszerűsített számla információit. A pénztárgép-adatok is anonimak, azonban azonosítóhoz kötötten megállapíthatóak az egyes adózókhoz tartozó tranzakciók, az adózó főtevékenysége, illetve a tranzakció tényleges helye is járási szinten. A járási mélységű OPG-adatbázis miatt az adatokból az üzleteket nem lehet egyértelmúen azonosítani, így az elemzések esetében az adózók azonos tevékenységgel rendelkező, járásonkénti, úgynevezett kiskereskedelmi egységeinek aggregált 
adataival dolgoztunk. ${ }^{1}$ Az OPG-adatok esetében a kérdőívvel azonos tartalmú információk (adózó éves bevétel, régió, főtevékenységet jelző TEÁOR-kód) mellett megvizsgáltuk az üzlet bevételét, életidejét - amiből lehet következtetni egy teljes évben nyitva tartó üzlet és egy újonnan nyitott üzlet közötti különbségekre -, az aktivitását - ami a nyitva tartott napok száma és az életidő hányadosát jelenti, és azt reprezentálja, hogy egy üzlet minden nap nyitva van, vagy esetleg csak 1-1 nap látogatható -, illetve az üzletben lebonyolított tranzakciók számát.

A kereskedők TEÁOR-tevékenységével kapcsolatosan megjegyzendő, hogy az adózó főtevékenysége nem feltétlenül egyezik meg a tényleges üzlettevékenységgel. A kiskereskedelmi kérdőíves adatok és az onlinepénztárgép-adatbázisok közötti további különbség, hogy míg előbbiek esetében az egységek közötti bevételmegoszlást nem lehetett megbontani üzletekre, így az adózók kártyaelfogadását vizsgáljuk, addig az onlinepénztárgép-adatok esetében az adózók tevékenységekre bontott adatait járásonként aggregáljuk, és ezen egységeket is tudjuk vizsgálni. A területi eloszlást nézve pedig míg a kérdőíves adat az adózó bejelentett helyét mutatja, addig a pénztárgép-adatbázisban a tranzakciók tényleges helye szerepel, ez azonban a reprezentativitást nem befolyásolja.

\section{A kártyaelfogadói hálózat fejlettsége}

A kérdőívek alapján a kiskereskedők és a vállalatok többsége egy értékesítési egységgel rendelkezik országosan, a kiskereskedők mindössze 3 százalékának van kettőnél több értékesítési egysége, míg ugyanez az arány a vállalkozásoknál 9 százalék. A közepes és nagyobb vállalkozások értékesítési egységeinek száma 1 és 23 között mozog. A vállalkozások esetében a minta kis elemszáma miatt nem lehetséges TEÁOR-kódonként külön vizsgálni a szektorokat, érdemes azonban megjegyezni, hogy a vállalkozások egymáshoz képest is nagyon különbözőek lehetnek. Így például míg egy építőipari vállalat vélhetően kevés értékesítési egységgel, de nagyobb forgalommal

\footnotetext{
${ }^{1}$ Az egység, amennyiben az adott adózónak abban a tevékenységi körben és járásban egy üzlete van, akkor az adott üzletet, ha több üzlete van, akkor az üzletek adatainak összesítését jelenti. Így az egységek száma kevesebb, mint a tényleges üzletek száma, míg az egy egységre jutó bevételek mértéke, tranzakciók darabszáma a ténylegesnél magasabb is lehet. A két fő vizsgált jellemzőt, a kártyaelfogadást és a készpénzhasználatot ez befolyásolhatja akkor, ha az adott járásban van adott adózóhoz tartozó azonos tevékenységű több üzlet is. Ha az üzletek mindegyike kártyaelfogadó, akkor a kártyaelfogadó üzletek arányát ez lefele torzítja, ha csak kártyát nem elfogadó üzleteket vonunk össze, akkor pedig felfele torzítja. Amennyiben van kártyaelfogadó és nem elfogadó üzlet is, akkor a több üzletből álló egység kártyaelfogadóként jelenik meg. Ez esetben, ha az eredeti kártyaelfogadási aránynál több az egységbe beolvasztott kártyaelfogadó üzletek aránya, akkor lefele, ha kevesebb, akkor pedig felfele torzítja az üzletek kártyaelfogadási arányát. Mint azt a későbbiekben bemutatjuk, a kérdőíves adatok alátámasztják azt az állítást, miszerint a kártyás fizetést nem biztosító üzletek szinte kizárólag a legnagyobb számosságú, legkisebb méretű, egy értékesítési egységgel rendelkező vállalkozások közül kerülnek ki, így valószínűsíthető, hogy kevés olyan eset van, amikor csak kártyát nem elfogadó üzletek kerülnek összevonásra, tehát az ebből fakadó felfele torzító hatás, ha van is, csak kis mértékű. A csak kártyát elfogadó, illetve vegyes elfogadó üzletek összevonásából fakadó torzítás is valószínúleg kicsi, mivel a kérdőív alapján a kiskereskedők mindössze 3 százalékának van kettőnél több értékesítési egysége. A készpénzhasználati arány esetében, mivel a kártyát nem elfogadó üzletek tranzakciói is beletartoznak az egység tranzakcióiba, a kártyaelfogadó üzletekben vizsgált készpénzhasználati arány felfele torzíthat, azaz magasabb a ténylegesnél.
} 
rendelkezik, és a kártyaelfogadás sem releváns, addig egy szállítmányozási cégnek vagy egy gépjárműjavító hálózatnak akár több értékesítési egysége is lehet, egyenként kisebb forgalommal, esetükben pedig a kártyaelfogadás releváns és általában biztosított. A vállalkozások körülbelül 40 százalékánál van lehetőség kártyás fizetésre, azonban ott, ahol van kártyaelfogadás, minden értékesítési egységben lehet kártyával fizetni. A kiskereskedők esetében átlagosan a közel 65 ezer értékesítési egység 71 százalékában lehet kártyával fizetni, azonban a kártyás fizetést nem biztosító üzletek szinte kizárólag a legnagyobb számosságú, legkisebb méretű, egy értékesítési egységgel rendelkező vállalkozások közül kerülnek ki. Az OPG-adatok alapján a kiskereskedők közel 60 ezer értékesítési egységének 58 százalékában lehet kártyával fizetni.

A felmérés kvalitatív kérdésekkel is vizsgálta a kártyaelfogadást, így a csak készpénzes fizetést biztosító válaszadók több lehetőséget is megjelölhettek arra vonatkozóan, hogy miért nem biztosítják a kártyás vásárlás lehetőségét. A nem kiskereskedő vállalatoknál a leginkább meghatározó indokot az jelentette, hogy a vevők azt nem igényelnék (61 százalék). Vélhetően a vállalatok egy jelentős részénél az előállított terméket kiskereskedők vagy akár további vállalatok vásárolják nagyobb tételben további árusításra vagy felhasználásra, vagy építkezés, illetve termelés a fő profiljuk, így esetükben a kártyás fizetés elfogadása nem releváns. További jelentősebb tényezők a magas POS-terminál- és banki költségek, a vállalatok 20-20 százaléka jelölte meg ezeket az indokokat. A kiskereskedők esetében is az jelentette a legjellemzőbb indokot, hogy a vásárlók nem igénylik a kártyás fizetés lehetőségét, a kártyát nem elfogadók 62 százaléka jelölte meg ezt az okot. Jelentős tényező volt a kártyaelfogadás költségoldala (magas banki díjak: 48 százalék; drága POS-terminálok: 29 százalék) és a kártyás vásárlás lassúsága (21 százalék). Emellett a válaszadók közel ötöde jelezte, hogy korábban már próbálták a kártyaelfogadást, de az nem volt sikeres.

Az OPG-adatbázisban a kereskedelmi egység éves bevétele, az adózó éves bevétele, a vásárlások átlagos értéke, a tranzakciók száma, a TEÁOR-kódok, az üzlet életideje, aktivitása is mind szignifikáns kapcsolatot mutatott a kártyaelfogadással. A régiókat vizsgálva nem mutatkozott lényeges különbség. ${ }^{2}$

A kiskereskedők és vállalatok kártyaelfogadását befolyásoló tényezőket döntési fa és logisztikus regresszió segítségével is vizsgáltuk, hogy a magyarázó változók egymásra ható hatásukat, az esetlegesen külső befolyásoló tényezőket kiszűrve láthassuk, mely tényezőknek van a legnagyobb hatásuk a vizsgált eredményváltozóra. A gépi tanuláson alapuló döntési fa segítségével azonosíthatjuk azokat a tényezőket, amelyek alapján a legkönnyebb eldönteni, hogy az adott kereskedő vagy vállalkozás ebben a konkrét vizsgálat esetében kártyaelfogadó-e. Emellett a logit regresszió olyan

\footnotetext{
${ }^{2}$ Az egyes változók részletesebb leírása a regressziók változóinak leírásánál található. A terjedelem miatt ezeket az alapstatisztikákat nem fejtjük ki jobban a tanulmányban, azonban ahogy a késóbbiekben látható, a legjelentősebb változó, a forgalom és a kártyaelfogadás közötti kapcsolatról a Fizetési Rendszer Jelentésben található részletesebb leírás. A 2019-es adatokról a 2020-ban megjelent kiadványban írtunk: https://www. $\mathrm{mnb}$.hu/letoltes/fizetesi-rendszer-jelentes-2020.pdf.
} 
statisztikai módszer, amelyeknél számszerúsíteni tudjuk a magyarázó változók parciális hatásait és szignifikanciájukat, azaz hogy tényleg van-e szignifikáns hatása a vizsgált magyarázó változóknak, illetve ha van, akkor az milyen irányú és mértékű változást okoz a kártyaelfogadás valószínúségében. A döntési fa elemei mutatják, hogy az adott vizsgálati körön belül az egységek milyen arányban kártyaelfogadóak (buborék felső értéke), és a vizsgált kör a teljes sokaságnak hány százaléka (a buborék alsó értéke), illetve, hogy a megjelenített változók az eredményváltozót legjobban befolyásoló magyarázó változók, amelyek mentén történik a homogén csoportokra bontás.

\section{1. ábra}

A döntési fák eredményei: kártyaelfogadást befolyásoló legfontosabb tényezők

Kiskereskedők (kérdőív)

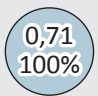

Árbevétel millió forintban $<21$

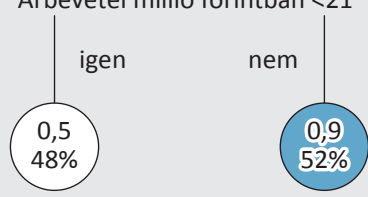

Vállalatok (kérdőív)

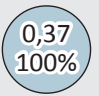

Készpénzes bérfizetés kategória $<2$

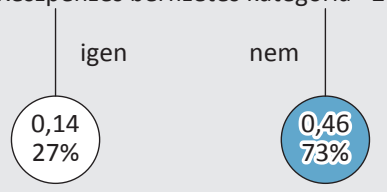

Kiskereskedők (OPG)

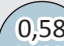

$100 \%$

Árbevétel millió forintban $<11$

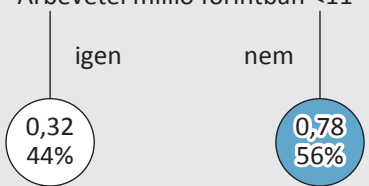

Forrás: Az MNB felmérései és a NAV onlinepénztárgép-adatai alapján végzett számítások

A kiskereskedői kérdőívek adatain készített döntési fa alapján a kártyaelfogadást az éves árbevétel befolyásolja a legnagyobb mértékben (1. ábra). A kiskereskedők 71 százaléka kártyaelfogadó, az évi 21 millió forint vagy annál nagyobb árbevételű kiskereskedők 90 százaléka fogad el kártyát, míg az ennél kisebb árbevételüeknek csupán az 50 százaléka. Érdemes megjegyezni, hogy az évi 21 millió forintos árbevétel havi kevesebb mint 2 millió forint bevételt jelent, ami nominálisan is alacsony érték, azaz már egy viszonylag alacsony bevételi szint elérésétől kezdődően igen magas kártyaelfogadási arányt láthatunk a kiskereskedők esetében. Vállalatok esetében az előző fejezetben említett szektorális eltérések miatt az árbevétel kevésbé volt meghatározó tényező a kártyaelfogadásban. A döntési fa alapján a készpénzes bérfizetés aránya befolyásolta legnagyobb mértékben a kártyaelfogadást. $A$ készpénzes 
bérfizetés aránya kategorikus változó, 1, ha a bérek 100 százaléka, 2, ha 56-99 százaléka 3, ha 45-55 százaléka, 4, ha 1-44 százaléka és 5, ha 0 százaléka kerül készpénzben kifizetésre. Azok a vállalatok, amelyek 100 százalékban készpénzben fizetik a béreket, jellemzően nem kártyaelfogadók, csupán 14 százalékuk fogad el kártyás fizetést. Ennek oka vélhetően a 3. fejezetben is bemutatott szektorális eltérés. Azok a vállalatok, amelyek a béreket jellemzően átutalással fizetik, nagyobb arányban (46 százalék) kártyaelfogadók. Az onlinepénztárgép-adatokra készített döntési fa alapján - összhangban a kérdőíves eredménnyel - a kiskereskedelmi egységek éves bevétele az a tényező, amelyik a legjobban befolyásolja a kártyaelfogadást. A 2019es adatok alapján az adatbázisban vizsgált kiskereskedelmi vállalkozások kereskedelmi egységeinek 58 százaléka kártyaelfogadó, ezen belül a már minimum 11 millió forint éves (havi kevesebb mint 1 millió forint) bevétellel rendelkező egységek 78 százaléka kártyaelfogadó, míg az ennél kevesebb éves bevétellel rendelkező üzletek esetében az üzletek 32 százalékánál lehetett kártyával fizetni 2019-ben (a teljes sokaság 44 százaléka tartozik ebbe a körbe). Az előző évekre is megnézve a döntési fákat, látszódik, hogy az évek során a kártyaelfogadási arány növekszik, ezen belül a homogén csoportok szétválasztásánál megjelenő éves bevétel értéke az évek során egyre csökken, azaz az alacsonyabb éves bevétellel rendelkező egységek esetében is egyre gyakoribb a kártyaelfogadás.

A különböző hatásokat logisztikus regresszió segítségével kiszűrve (magyarázó változók korreláltsága, endogenitási problémák) megvizsgáljuk, hogy az egyes magyarázó változók ténylegesen hatnak-e (szignifikánsak-e) az eredményváltozóra, és ha igen, milyen irányú a hatásuk. A logisztikus regresszió függő változójának értéke a döntési fához hasonlóan 1 , ha van, és 0 , ha nincs az adott kiskereskedőnél vagy vállalatnál bankkártya-elfogadás. A regresszióban magyarázó változóként szerepelnek területi jellemzők, mivel a gazdaságilag eltérő fejlettségű régiókban eltérő lehet a kártyaelfogadás valószínűsége, valamint a kiskereskedő és vállalat jövedelmi helyzetét és fizetési szokásait leíró változók, mivel a döntési fa alapján is a méret kategóriára és a fizetési szokásokra vonatkozó változók nagyban befolyásolják a kártyaelfogadást. A magyarázó változók segítségével összetett hatásokat is tudunk vizsgálni a kártyaelfogadásra. Az 1. táblázatban a kiskereskedői, vállalati kérdőívekre, illetve az onlinepénztárgép-adatokra alkalmazott logisztikus regresszió esélyhányadosait mutatjuk be. Amennyiben az adott magyarázó változó esélyhányadosa 1 alatt van, akkor csökkenti, ha 1 fölött van, akkor növeli a kártyaelfogadás valószínűségét. A táblázatban szerepeltetett modelljeinkben mindegyik magyarázó változó esetében szignifikáns hatás mutatkozott a vizsgált 95 százalékos konfidenciaszinten.

A vállalatok és a kiskereskedők kártyaelfogadását vizsgálva egyaránt igaz, hogy a magyarázó változók esetében a homogenitásra törekedve a készpénzben történő munkabérfizetést végül dummy változóként tettük bele a modellünkbe, az 55 százalék felett főleg készpénzben fizetőnek, az alatt pedig elsősorban nem készpénzfizetőnek tituláltuk az adott kereskedőt, vállalatot. Területileg is az látható, hogy régiók helyett érdemesebb inkább a nagyrégiókat vizsgálni. 
A vállalati kérdőívek adatain vizsgált logisztikus regressziókhoz a következő egyenletet írtuk fel:

$$
\begin{gathered}
y=\beta_{0}+\beta_{1} \ln (\text { Árbevétel })+\beta_{2} \text { Nagyrégió }+\beta_{3} \text { Településtípus }+ \\
\beta_{4} \text { Értékesítésiegységekszáma }+\beta_{5} \text { Munkabérfizetésekészpénzben }+\beta_{6} T E A ́ O R+\varepsilon
\end{gathered}
$$

Kiskereskedők esetében nem lett szignifikáns a településtípus $\left(\beta_{3}=0\right)$, míg a vállalatok esetében a kis mintaelemszám és a szerteágazó területeket érintő főtevékenységek miatt a TEÁOR-kódok maradtak ki a végleges modellből $\left(\beta_{6}=0\right)$.

Az egyenletben:

- a függő változó:

- y: van-e a vizsgált kiskereskedőnél vagy vállalatnál kártyaelfogadás ( 0 vagy 1 )

- a magyarázó változók:

- az éves bruttó árbevétel logaritmusa

- nagyrégió-kód (Közép-Magyarország, Dunántúl, Alföld és Észak)

- településtípus: az adott település típusa (Budapest, Megyei jogú város, Város, Község)

- értékesítési egységek száma

- munkabér fizetése készpénzben ( 0 =a munkabéreket elsősorban nem készpénzben fizetik, 1=föleg készpénzben fizetik a béreket)

- TEÁOR ${ }^{3}$ : a válaszadó fötevékenysége

Az online pénztárgép eltérő adatszerkezete miatt az ezekre az adatokra alkalmazott logisztikus regresszió egyenlete is eltér az előzőtől:

$$
\begin{gathered}
y=\beta_{0}+\beta_{1} \ln (\text { Árbevétel })+\beta_{2} \text { Tranzakciókszáma }+\beta_{3} \ln (\text { Átlagosvásárlásiérték })+ \\
\beta_{4} \text { Életidő }+\beta_{5} \text { Aktivitás }+\beta_{6} T E A ́ O R+\varepsilon
\end{gathered}
$$

Az egyenletben:

- a függő változó:

- y: van-e a vizsgált kiskereskedelmi egyégben kártyaelfogadás ( 0 vagy 1 )

- a magyarázó változók:

- a kiskereskedelmi egység éves bruttó árbevételének logaritmusa ${ }^{4}$

- a kiskereskedelmi egység által lebonyolított tranzakciók száma az adott évben

- a kiskereskedelmi egységben lebonyolított tranzakciók átlagos értékének ${ }^{5}$ logaritmusa

- a kiskereskedelmi egység életideje (az évben az első és az utolsó tranzakciójának napja között eltelt napok száma)

- a kiskereskedelmi egység aktivitása (azon napok száma, amelyen tényleges tranzakció történt /az üzlet életideje)

- TEÁOR: az adózó főtevékenysége

${ }^{3}$ Gazdasági tevékenységek egységes ágazati osztályozási rendszere, 2008

${ }^{4} \mathrm{~A}$ kereskedelmi egység és az adózó éves bevételét is vizsgáltuk, és az üzlet bevétele illett jobban a modellbe.

${ }^{5} \mathrm{Az}$ átlagos vásárlás értékét az éves bevételnek és az éves tranzakciók számának hányadosával számoltuk. 


\begin{tabular}{|c|c|c|c|}
\hline \multicolumn{4}{|c|}{$\begin{array}{l}\text { 1. táblázat } \\
\text { Logisztikus regressziók eredményei a vállalati és kiskereskedői kártyaelfogadásra } \\
\text { (esélyhányadosok) }\end{array}$} \\
\hline Változó & Vállalatok & Kiskereskedők & $\begin{array}{l}\text { Kiskereskedők } \\
\text { (OPG) }\end{array}$ \\
\hline Az árbevétel logaritmusa & $\begin{array}{c}1,12^{*} \\
(87,34)\end{array}$ & $\begin{array}{c}2,65^{*} \\
(73,50)\end{array}$ & $\begin{array}{c}2,52^{*} \\
(-90,72)\end{array}$ \\
\hline A tranzakciók száma & - & - & $\begin{array}{c}1,00 * \\
(-9,61)\end{array}$ \\
\hline Az átlagos vásárlási érték logaritmusa & - & - & $\begin{array}{l}1,08^{*} \\
(5,93)\end{array}$ \\
\hline Életidő & - & - & $\begin{array}{c}0,99 * \\
(-0,01)\end{array}$ \\
\hline Aktivitás & - & - & $\begin{array}{l}1,85^{*} \\
(0,62)\end{array}$ \\
\hline \multicolumn{4}{|l|}{ Nagyrégió (Közép-Magyarország) } \\
\hline Dunántúl & $\begin{array}{c}0,87^{*} \\
(-24,66)\end{array}$ & $\begin{array}{l}1,16^{*} \\
(4,49)\end{array}$ & - \\
\hline Alföld és Észak & $\begin{array}{c}0,77^{*} \\
(-43,68)\end{array}$ & $\begin{array}{c}0,51^{*} \\
(-21,29)\end{array}$ & - \\
\hline \multicolumn{4}{|l|}{ Településtípus (Főváros) } \\
\hline Megyei jogú város & $\begin{array}{c}1,28^{*} \\
(38,50)\end{array}$ & - & - \\
\hline Város & $\begin{array}{c}0,69 * \\
(-63,48)\end{array}$ & - & - \\
\hline Község & $\begin{array}{c}0,72 * \\
(-40,86)\end{array}$ & - & - \\
\hline \multicolumn{4}{|l|}{$\begin{array}{l}\text { TEÁOR (471: nem szakosodott bolti vegyes } \\
\text { kiskereskedelem) }\end{array}$} \\
\hline $\begin{array}{l}472 \text { (szakosodott bolt, pl. hentes, pék, dohány, } \\
\text { zöldséges) }\end{array}$ & - & $\begin{array}{c}0,46 * \\
(-18,47)\end{array}$ & $\begin{array}{l}0,93 * \\
(-2,05)\end{array}$ \\
\hline 473 (gépjármű-üzemanyag) & - & $\begin{array}{l}1,00 * \\
(0,00)\end{array}$ & $\begin{array}{c}0,54^{*} \\
(-4,86)\end{array}$ \\
\hline 474 (IT, műszaki, telekommunikáció) & - & $\begin{array}{c}0,44^{*} \\
(-10,40)\end{array}$ & $\begin{array}{l}1,21^{*} \\
(2,70)\end{array}$ \\
\hline $\begin{array}{l}475 \text { (egyéb háztartási cikk, pl. textil, bútor, } \\
\text { villamos kisgép) }\end{array}$ & - & $\begin{array}{c}0,28 * \\
(-27,95)\end{array}$ & $\begin{array}{c}0,54 * \\
(-14,46)\end{array}$ \\
\hline $\begin{array}{l}476 \text { (kultúra, szabadidő: könyv, újság, sportszer, } \\
\text { játék) }\end{array}$ & - & $\begin{array}{c}1,86^{*} \\
(11,50)\end{array}$ & $\begin{array}{l}1,67^{*} \\
(9,29)\end{array}$ \\
\hline 477 (ruha, cipő, gyógyszer, illatszer) & - & $\begin{array}{c}0,44^{*} \\
(-21,87)\end{array}$ & $\begin{array}{c}0,93^{*} \\
(-2,52)\end{array}$ \\
\hline 478 (piaci kiskereskedelem) & - & $\begin{array}{c}0,13^{*} \\
(-43,33)\end{array}$ & $\begin{array}{c}0,53^{*} \\
(-8,14)\end{array}$ \\
\hline $\begin{array}{l}479 \text { (nem bolti, csomagküldő, internetes } \\
\text { értékesítés) }\end{array}$ & - & $\begin{array}{c}0,19 * \\
(-29,83)\end{array}$ & $\begin{array}{c}0,4^{*} \\
(-15,67)\end{array}$ \\
\hline Az értékesítési egységek száma & $\begin{array}{c}3,48^{*} \\
(216,40)\end{array}$ & $\begin{array}{c}4,25^{*} \\
(12,82)\end{array}$ & - \\
\hline Munkabér fizetése készpénzben & $\begin{array}{c}0,23 * \\
(-307,21)\end{array}$ & $\begin{array}{c}0,51^{*} \\
(-25,57)\end{array}$ & - \\
\hline Konstans & $\begin{array}{c}0,18^{*} \\
(-201,85)\end{array}$ & $\begin{array}{c}0,12^{*} \\
(-17,25)\end{array}$ & $\begin{array}{l}-14,07^{*} \\
(-90,72)\end{array}$ \\
\hline $\mathbf{R}^{2}$ & 0,12 & 0,3 & 0,3 \\
\hline $\mathbf{N}$ & 300 & 300 & 57848 \\
\hline
\end{tabular}

Megjegyzés: * 95 százalékos konfidenciaszinten szignifikáns együtthatók, zárójelben a z-próbák értékei Forrás: Az MNB felmérései és a NAV onlinepénztárgép-adatai alapján végzett számítások 
A kérdőív adatain végzett regressziós eredmények alapján a vállalkozások méretével együtt nő a kártyaelfogadás valószínűsége: a kiskereskedők és vállalatok árbevétele, valamint az értékesítési egységek száma is pozitiv kapcsolatot mutat a kártyaelfogadással, azaz minél nagyobb a vállalat, annál valószínúbb, hogy biztosítja ügyfeleinek ezt a fizetési módot, összhangban Looke (2007) és Kosse et al. (2017) megállapításaival, valamint Ilyés - Vargának (2018) a hazai helyzetet bemutató korábbi elemzésével.

Területi szempontból jellemzően alacsonyabb a kártyaelfogadás valószínúsége a közép-magyarországihoz képest a másik két nagyrégióban. Ez alól kivételt a kiskereskedők esetében a Dunántúli nagyrégió jelent, amelyet egyrészt a nagyrégió fejlett turizmusa és kiskereskedelme magyaráz, másrészt az, hogy a mintában csak az 1 milliárd forint éves árbevétel alatti kiskereskedők szerepeltek. Az Alföldet és Észak-Magyarországot magában foglaló nagyrégió esetében a legalacsonyabb a kártyaelfogadás a kiskereskedőknél és a vállalatoknál egyaránt. A településtípusok esetében Budapesthez viszonyítva a megyei jogú városokban szignifikánsan több, míg az egyéb városokban és a községekben alacsonyabb a kártyaelfogadás valószínúsége. A területi kártyaelfogadási adatok összhangban vannak Kajdi - Nemecskó (2020) korábbi eredményeivel.

A munkabérek kifizetése a vállalatoknál főleg átutalással történik, ugyanakkor a munkabérek készpénzes kifizetése negatívan befolyásolja a kártyaelfogadás valószínúségét. Vélhetően azoknál a kiskereskedőknél és vállalatoknál, ahol a kimenő fizetések (pl. munkabér) nagy része készpénzben történik, a bejövő készpénzes fizetést is előnyben részesítik a kártyás fizetéssel szemben, ami negatívan befolyásolja a kártyaelfogadást.

A főtevékenységek vizsgálata alapján a kereskedők is szegmentálhatók kártyaelfogadás szempontjából: a nem szakosodott kiskereskedőkhöz hasonlóan magas a kártyaelfogadás valószínúsége a benzinkutaknál és a kulturális területen (újságosok, könyvesboltok), ugyanakkor jelentős tér van még a fejlesztésre a piaci kiskereskedők és a kisebb szakosított kereskedők esetében.

Az onlinepénztárgép-adatokkal végzett regresszió is alátámasztja a kiskereskedelmi egységek árbevétele és a kártyaelfogadás közötti pozitív kapcsolatot.

A tevékenységi körök tekintetében szinte minden esetben azonos az eredmény a kérdőíves eredményekkel, de a gépjármű-üzemanyag, illetve az IT, műszaki cikkek, telekommunikációs tevékenységú üzletek esetében a pénztárgép ellentétes irányt mutat a referenciatevékenységhez képest, azaz eszerint a gépjármú-üzemanyag esetében nem egyenlő, hanem kisebb az elfogadás valószínűsége a bolti vegyeskereskedéshez képest, az IT, műszaki cikkek, telekommunikációs tevékenységú üzletek esetében pedig nagyobb az elfogadási valószínűség. Ezt az eltérést okozhatja a kérdőív kis mintaelemszáma. Az eredmények értelmezése esetében figyelembe 
kell venni, hogy a vizsgált TEÁOR-kód az adózó bejelentett fő tevékenységét jelzi, azaz eltérhet a tényleges tevékenységi körtől.

Ugyan Looke (2007) szintén arra jutott, hogy a kereskedő tevékenységi köre is befolyásolja a kártyaelfogadás valószínűségét, ezt egy lényegesen egyszerübb, háromkategóriás változóval vizsgálta, így az eredmények közvetlenül nem hasonlíthatók össze. A kérdőívhez képesti új változók esetében további információ, hogy az erősen szignifikánsan ható tranzakciók száma minimálisan ugyan, de csökkenti az elfogadási valószínúséget, ami a sok kisebb értékű terméket árusító boltok kártyát nem elfogadására irányul.

Az átlagos vásárlási érték is pozitív kapcsolatot mutat a kártyaelfogadással, ami összhangban áll a korábbi tanulmányok eredményeivel, miszerint a nagyobb értékü áruk esetében jellemzőbb a kártyás fizetés, ami így, közvetetten az elfogadást is befolyásolja.

Az üzlet életideje negatív kapcsolatot mutat, ami utalhat arra, hogy az újonnan nyitott boltok esetében jellemző, hogy kártyaelfogadóak. Az üzlet aktivitását tekintve a hét minél több napján van nyitva az adott bolt, annál nagyobb valószínűséggel kártyaelfogadó. A területi eltérést ugyanúgy vizsgáltuk ennél az elemzésnél, azonban ennél az adatbázisnál nem lett szignifikáns változó a kártyaelfogadás tekintetében, ez a korábbi fejezetben leírt üzletek egyértelmű azonosíthatatlanságából fakadó torzító hatás miatt is lehet.

\section{Forgalmi adatok}

A kérdőíves felmérés során a vállalatoknak és kiskereskedőknek részletesen meg kellett adniuk kimenő és bejövő pénzforgalmukat darabszám és érték szerint is, az egyes fizetési módok szerinti bontásban. Ezek alapján lehetőség nyílik pontos képet kapni például azokról a vállalkozási típusokról, ahol jellemzőbb az intenzív készpénzhasználat, de azonosíthatók a bejövő (az eladott áruk vagy szolgáltatások ellenértékeként kapott), illetve a kimenő (a beszállítók és alkalmazottak felé irányuló) fizetések módja is, ez utóbbi az OPG-adatokhoz képest is többlet információt jelent.

A bejövő fizetési forgalom vizsgálatánál azonosíthatók bizonyos alapvető tendenciák. A kiskereskedők felé irányuló pénzforgalomra jellemzőbb a vállalatokhoz képest az intenzívebb készpénzhasználat, a bejövő fizetések körülbelül 80 százaléka bonyolódik le ilyen módon (2. ábra). Ez az arány összhangban van az onlinepénztárgép-adatbázison végzett elemzések eredményeivel is. A régió más országaiból Górkának (2012) a lengyel kiskereskedői piacot bemutató tanulmányának eredményeivel érdemes összevetni a sajátjainkat. Górka tanulmánya a fizikai elfogadóhelyeknél közel 90 százalékos készpénzhasználatot mutatott. Meg kell jegyezni ugyanakkor, hogy az ezen elemzés óta eltelt időszakban feltehetően Lengyelországban is csökkent 
a készpénzhasználat. Az Európai Központi Bank legfrissebb elemzése (ECB 2020) a lakossági fizetési szokásokról indirekt módon, azaz nem a kereskedők, hanem a vásárlók szokásait felmérve szintén arra jutott, hogy a kiskereskedelmi fizetéseknél a legtöbb európai országban hasonló arányok mutatkoznak, azaz fizikai vásárlási helyzetekben továbbra is egyértelműen a készpénz dominál. Mind a kiskereskedőknél, mind a vállalatoknál az érték szerinti megoszlást nézve elmondható, hogy alacsonyabb a készpénzes fizetések értékének aránya, ami a viszonylag kis számú, de nagy értékú elektronikus átutalásra vezethető vissza. A kimenő pénzforgalom vizsgálatánál is hasonló tendenciák állapíthatók meg.

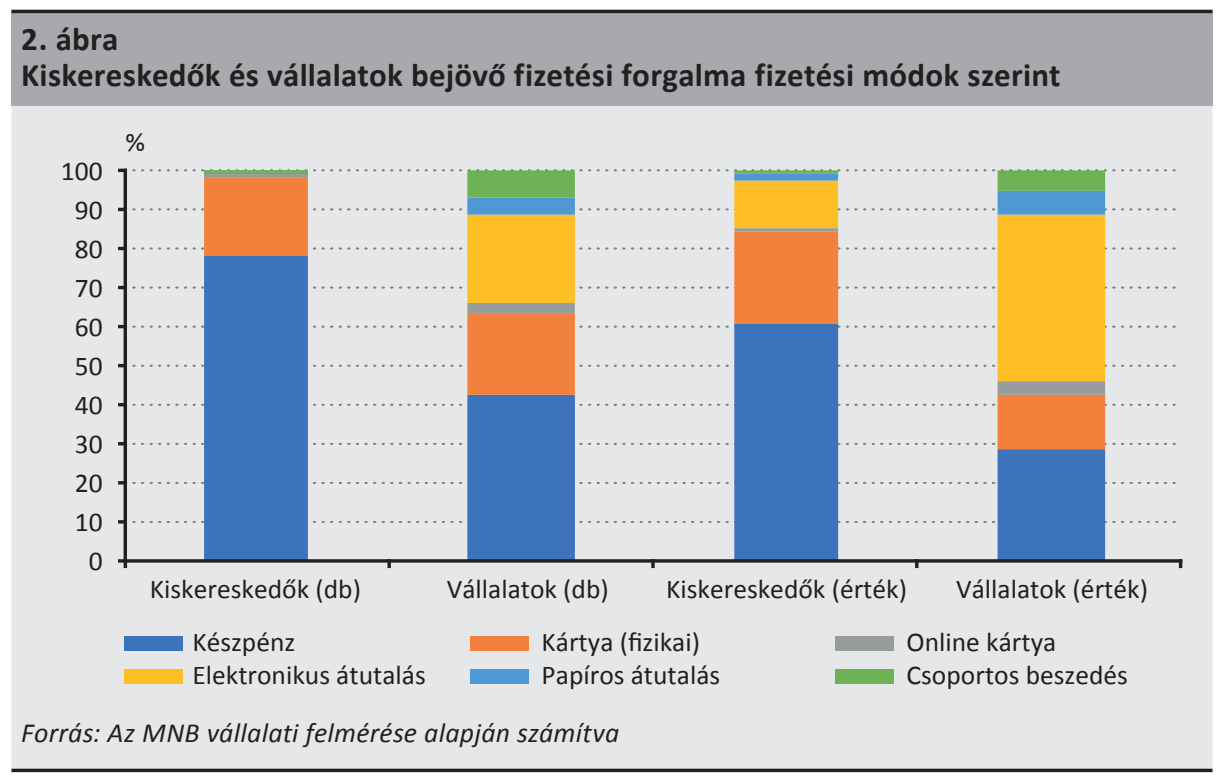

\subsection{Létszám-kategória szerinti eltérések}

A vállalati adatok elemzéséhez a mintát csoportokra osztottuk létszám-kategória szerint. A különböző méretű vállalkozások forgalmi adatai nagyban különbözhetnek egymástól, ezért a következő kategóriákat alkalmaztuk: 0-9 fő, 10-19 fő, 20-49 fő, 50-249 fő, 250 fő fölötti.

A beérkezett válaszok alapján jelentős különbség látszik az eltérő méretű vállalatok között a beérkező tranzakciók fizetési módok szerinti megoszlásában. Míg a kisebb (50 fő alatti) vállalatoknál a bejövő fizetések körülbelül 40-50 százaléka készpénzes fizetés, a kártyás, illetve egyéb elektronikus fizetések aránya 20-20 százalék (3. ábra). A nagyobb vállalkozások esetében a készpénzes fizetések aránya visszaszorult, esetükben a készpénzes, a kártyás (fizikai és online) és elektronikus átutalásos bejövő fizetések száma kiegyenlítődik (25-35-28 százalék). A legnagyobb vállalatoknál (250 fő feletti) a bejövő fizetések körülbelül 85 százaléka elektronikus átutalással 
történik, a többi fizetési mód aránya minimális. A bejövő fizetéseket érték szerint vizsgálva hasonló tendenciák láthatók, de az elektronikus átutalások részaránya még magasabb. Eredményeink tehát összhangban vannak a Belházyné et al. (2018) által feltárt készpénzhasználat és vállalatméret közötti összefüggésekkel.

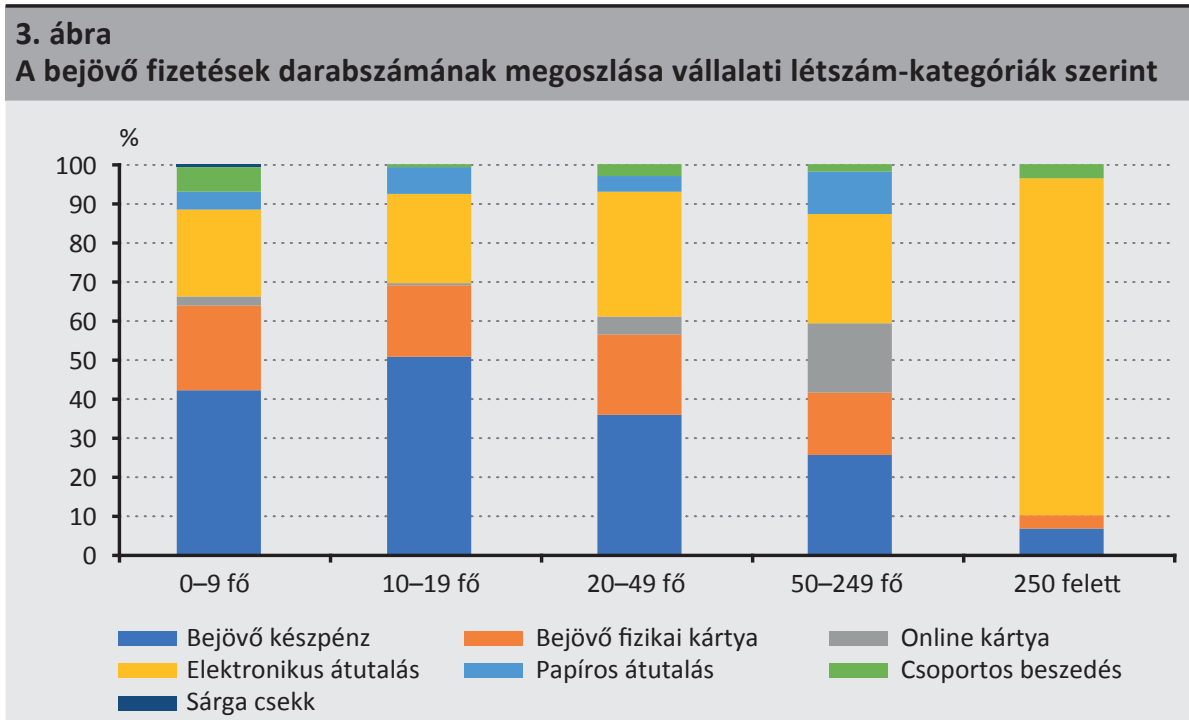

Megjegyzés: A mintaelemszámok: 0-9 fö: 95 vállalat, 10-19 fö: 90 vállalat 20-49 fö: 27 vállalat, 50-249 fö: 24 vállalat, $250+$ fö: 6 vállalat

Forrás: MNB vállalati felmérés alapján számítva

Összességében megállapíthatjuk, hogy a vállalatok esetében elterjedtek az elektronikus fizetési módok. A készpénzforgalom csökkentése elsősorban a kisebb, 50 fő alatti vállalatok esetében lehet továbbra is lényeges célkitűzés.

A kiskereskedők esetében is megvizsgáltuk az egyes fizetési módok forgalmának alakulását, azonban némi eltéréssel. Egyrészt a kisebb foglalkoztatotti létszámú kereskedők száma jóval nagyobb, ezért a legkisebb kategóriát tovább bontottuk, míg 50 fő feletti létszámmal rendelkező kiskereskedő nem került a mintába. Másrészt a kiskereskedelemben csak a készpénz, kártya és egyéb fizetési módokat különítettük el a bejövő fizetéseknél. Ebben a szegmensben is elmondható, hogy a méret növekedésével párhuzamosan nő az elektronikus (kártyás) fizetések aránya: míg a legkisebb kategóriában a fizetések több mint 90 százaléka történt készpénzben, addig a legnagyobb kategóriában ez már lecsökkent 60 százalékra (4. ábra). 


\section{4. ábra \\ A bejövő fizetések darabszámának megoszlása létszám-kategóriák szerint a kiskereskedőknél}

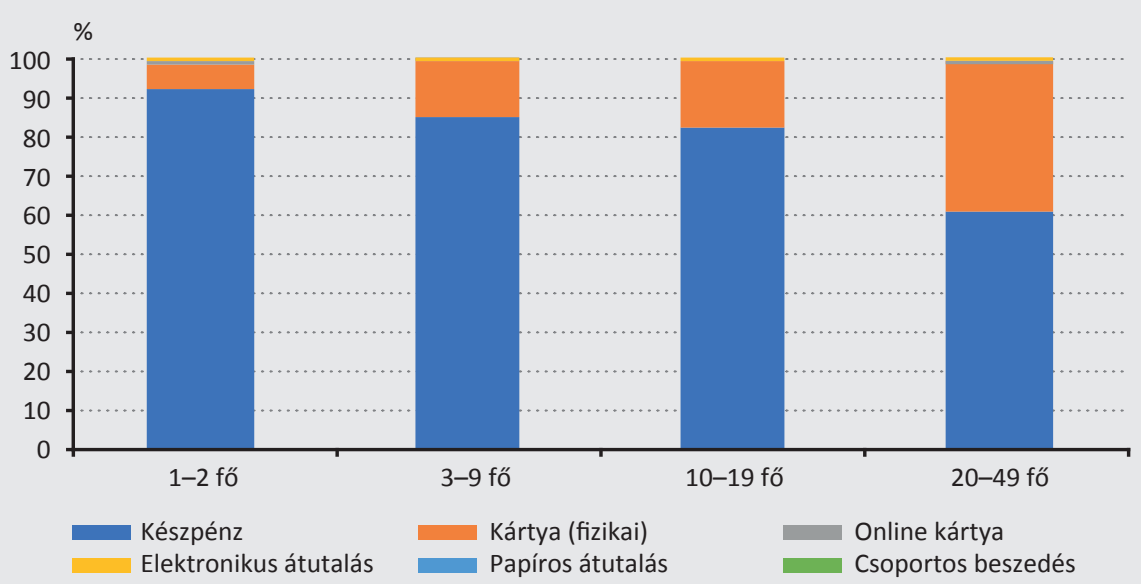

Megjegyzés: A mintaelemszámok: 1-2 fő: 177 kiskereskedő, 3-9 fő: 106 kiskereskedő, 10-19 fő: 10 kiskereskedö, 20-49 fö: 7 kiskereskedö

Forrás: Az MNB kiskereskedői felmérése alapján számítva

A bejövő fizetések értéke szerinti vizsgálatnál a kiskereskedők esetében is jellemző az átutalások fogadása, a 10 fö alatti cégeknél ezek részaránya még 20 százalék alatti, míg a nagyobb kereskedőknél 30-35 százalék körüli. Az adatok alapján tehát az átutalások használata a kiskereskedői szektorban nem széleskörű, inkább kevés esetben, nagy értékű tranzakciók teljesítése történik ilyen módon. Ha csak a kártyát elfogadó kereskedőket vesszük figyelembe, akkor sem változik jelentősen a kép, sem a darabszám, sem az érték szerinti megoszlás tekintetében. Ez azt mutatja, hogy a kártyaelfogadást nem biztosító kereskedők (készpénzes) forgalma viszonylag marginális a teljes szektor szempontjából, ez a megállapítás igaz az online pénztárgép adatbázisában vizsgált kiskereskedelmi egységek esetében is. 


\subsection{A készpénzhasználatot meghatározó föbb tényezők}

Közpolitikai szempontból kiemelten fontos lehet, hogy azonosítani tudjuk azokat a tényezőket, amelyek miatt a vállalkozások a készpénzhasználatot preferálják az elektronikus fizetési módokkal szemben, ugyanis a további pénzforgalmi szabályozási intézkedéseket, illetve fejlesztési projekteket ezek ismeretében célzottabban lehet kialakítani. Először döntési fa előállításával megnéztük, hogy melyek azok a legfontosabb tényezők, amelyek meghatározzák a kártyaelfogadó üzletekben a bejövő készpénz arányát a teljes forgalmon belül, majd az ok-okozati összefüggések feltérképezéséhez statisztikailag jobban értelmezhető és a szelekciós hatást kezelő Heckman-féle szelekciós modellt alkalmaztuk, az utóbbi esetben a teljes sokaságot vizsgáltuk, itt a kétlépcsős regresszión alapuló modell a kártyaelfogadás és nem elfogadás miatti különbségeket is kezeli.

A döntési fákat vizsgálva a kiskereskedelmi kérdőív alapján a kártyaelfogadó üzletekben a bejövő készpénzes tranzakciók arányát legnagyobb mértékben befolyásoló tényező a készpénzes bérfizetés aránya ${ }^{6}$, emellett a TEÁOR-kód is a többi tényezőnél nagyobb hatással van a készpénzhasználatra (5. ábra). Azoknál a kiskereskedőknél, ahol magas a készpénzes bérfizetés aránya, a bejövő készpénzes fizetések darabszámának aránya is magasabb. A vállalati adatok alapján is a készpénzes bérfizetés a készpénzhasználatot legnagyobb mértékben befolyásoló tényező, azaz azoknál a vállalatoknál, ahol a készpénzes bérfizetés jellemző, ott a bejövő készpénzes tranzakciók aránya is magasabb.

Az onlinepénztárgép-adatokon belül a kártyaelfogadó üzletekben történt bejövő készpénzes tranzakciók arányát vizsgálva a döntési fa alapján az átlagos vásárlási érték szerint lehet a leginkább homogén csoportokat kialakítani, vagyis ez a készpénzarányt legjobban befolyásoló tényező. A kártyaelfogadó kiskereskedelmi egységek összességében 81 százalékos a bejövő készpénzes tranzakciók aránya. Ha egy adott kiskereskedelmi egységben az átlagos vásárlási érték kisebb 3753 forintnál, akkor jellemzően 88 százalékos a készpénzfizetési arány (az üzletek 61 százaléka ebbe a kategóriába esik), míg ha ennél nagyobb az átlagos vásárlási érték, akkor 68 százalékos a készpénzfizetési arány. További csoportokra lehet bontani az egységeket az átlagos vásárlási érték további megbontásával.

\footnotetext{
${ }^{6}$ A készpénzes bérfizetés aránya kategorikus változó, 1, ha a bérek 100 százaléka, 2, ha 56-99 százaléka, 3, ha 45-55 százaléka, 4, ha 1-44 százaléka és 5, ha 0 százaléka kerül készpénzben kifizetésre.
} 


\section{5. ábra \\ Döntési fa eredmények: a bejövő készpénzes tranzakciók arányát befolyásoló legfontosabb tényezők}

Kiskereskedők (kérdőív)

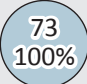

Készpénzes bérfizetés kategória $>=2$

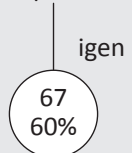

TEÁOR-kód=473,476

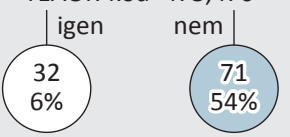

Vállalatok (kérdőív)

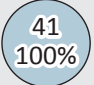

Készpénzes bérfizetés kategória >=2

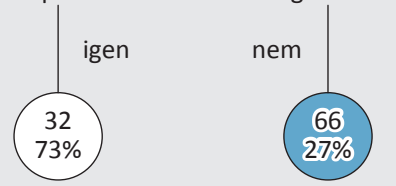

Kiskereskedők (OPG)

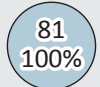

Átlagos vásárlás értéke $>=3753 \mathrm{Ft}$
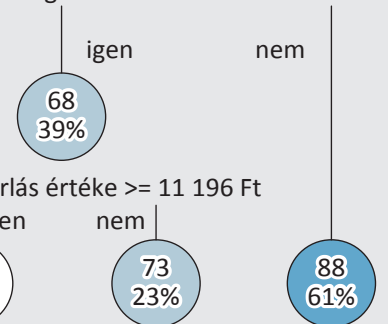

Forrás: Az MNB felmérései és a NAV onlinepénztárgép-adatai alapján végzett számítások

Lineáris regresszió segítségével vizsgáltuk, hogy milyen egyéb tényezők lehetnek hatással a készpénzes tranzakciók arányára. A regresszióban csak a kártyaelfogadó kiskereskedőket és vállalatokat vizsgáltuk, ezért a lehetséges szelekciós torzítást Heckman-korrekcióval kezeltük. A regresszióban, mivel az eredményváltozó 0-1 közé szúkített érték, a készpénzhasználati arány logit transzformálására van szükség, így az eredményváltozó

$$
y=\ln [(\text { Készpénzarány+ } \mu) /(1-\text { Készpénzarány }+\mu)],
$$


$\mu=0,00001$ konstans (így 1 és 0 készpénzarányra is értelmes az összefüggés). Az eredményváltozó így a készpénz, nem készpénz arány alakulására adhat magyarázatot. A lineáris regressziók a kiskereskedői és vállalati mintákra az alábbi egyenlettel írhatók fel:

$$
\begin{gathered}
y=\beta_{0}+\beta_{1} \text { Létszámkategória }+\beta_{2} \text { TEÁOR }+\beta_{3} \text { Internetesértékesítés }+ \\
\beta_{4} \text { Készpénzeskifizetésekaránya }+ \text { Lambda }+\varepsilon
\end{gathered}
$$

A vállalatok esetében a kis mintaelemszám és a szerteágazó területeket érintő főtevékenységek miatt a TEÁOR-kódok ebből a modellből is kimaradtak. A kiskereskedők esetében a modellben csak azokat a válaszadókat vizsgáltuk, akiknél van kártyaelfogadás. Megvizsgáltuk a hasonló modelleket a készpénzes tranzakciók darabszáma helyett az értéküket alapul véve. Ezek hasonló eredményeket hoztak, ugyanakkor magyarázó erejük gyengébb lett, így itt nem szerepeltetjük őket.

Az egyenletben:

- a függő változó:

$-y=\ln [($ Készpénzarány+ $\mu) /(1-K e ́ s z p e ́ n z a r a ́ n y+\mu)], \mu=0,00001$ konstans. A készpénzes tranzakciók darabszámának és a nem készpénzes tranzakciók darabszámának aránya.

- a magyarázó változók:

- a válaszadó vállalkozás létszám-kategória szerinti besorolása

- TEÁOR: a válaszadó főtevékenysége

- internetes értékesítési kétértékü (dummy) változó: 0, ha nincs online értékesítés, 1 , ha van

- a készpénzes tranzakciók darabszámának aránya az összes kimenő tranzakció között (0-100 százalék között)

- Lambda (Inverz Mills ratio)

Az onlinepénztárgép-adatbázis szerkezeti különbsége miatt az erre alkalmazott regresszió egyenlete:

$$
\begin{gathered}
y=\beta_{0}+\beta_{1} \text { Régió }+\beta_{2} T E A ́ O R+\beta_{3} \ln (\text { Árbevétel })+\beta_{4} \text { Tranzakciókszáma }+ \\
\beta_{5} \ln (\text { Átlagosvásárlásiérték })+\beta_{6} \text { Üzletéletideje }+\beta_{7} \text { Üzletaktivitása }+ \text { Lambda }+\varepsilon
\end{gathered}
$$

Az egyenletben:

- a függő változó:

- $y=\ln [($ Készpénzarány $+\mu) /(1-K e ́ s z p e ́ n z a r a ́ n y+\mu)], \mu=0,00001$ konstans. A készpénzes tranzakciók darabszámának és a nem készpénzes tranzakciók darabszámának aránya az online pénztárgépben definiált kiskereskedelmi egységek tranzakciói között 
- a magyarázó változók:

- régiókód, Közép-Magyarországba Budapestet is besoroltuk

- TEÁOR: a tranzakcióhoz tartozó adózó fótevékenysége

- a kiskereskedelmi egységhez tartozó adózó éves bruttó árbevételének logaritmusa

- a kiskereskedelmi egységben lebonyolított tranzakciók száma az adott évben (ezer darab)

- a kiskereskedelmi egységben lebonyolított tranzakciók átlagos értékének logaritmusa

- a kiskereskedelmi egység életideje (az évben az első és az utolsó tranzakciójának napja között eltelt napok száma

- a kiskereskedelmi egység aktivitása (azon napok száma, amelyen tényleges tranzakció történt /az üzlet életideje)

- Lambda (Inverz Mills ratio)

A regressziók eredményeit a 2. táblázatban jelöltük. Az egyes cellák az oszlopban jelölt adatbázison készített elemzések szignifikáns magyarázó változóinak együtthatóink exponenciális hatványát tartalmazzák, ami az egységnyi változás esetében az eredményváltozóban bekövetkező változás nagyságát jelöli, zárójelben pedig a t-érték látható.

2. táblázat

A készpénzhasználatot magyarázó lineáris regressziók becsült együtthatói

\begin{tabular}{|c|c|c|c|}
\hline Változó & Vállalatok & Kiskereskedők & Kiskereskedők (OPG) \\
\hline \multicolumn{4}{|l|}{ Létszám-kategória (3 fő alatti) } \\
\hline 3 és 9 fő között & $\begin{array}{c}0,27^{*} \\
(-161,78)\end{array}$ & $\begin{array}{c}0,22 * \\
(-47,94)\end{array}$ & - \\
\hline 10 és 19 fő között & $\begin{array}{c}0,75^{*} \\
(-9,18)\end{array}$ & $\begin{array}{c}0,20 * \\
(-37,71)\end{array}$ & - \\
\hline 20 és 49 fő között & $\begin{array}{c}0,34^{*} \\
(-25,92)\end{array}$ & - & - \\
\hline 50 fő fölött & $\begin{array}{c}0,12^{*} \\
(-32,26)\end{array}$ & - & - \\
\hline \multicolumn{4}{|l|}{ Régió (Közép-Magyarország) } \\
\hline Észak-Magyarország & $\begin{array}{c}2,10^{*} \\
(52,96)\end{array}$ & - & $\begin{array}{l}1,64^{*} \\
(8,32)\end{array}$ \\
\hline Észak-Alföld7 & $\begin{array}{c}0,90 * \\
(-86,69)\end{array}$ & - & $\begin{array}{l}1,34^{*} \\
(5,61)\end{array}$ \\
\hline Dél-Alföld & $\begin{array}{c}1,34^{*} \\
(21,18)\end{array}$ & - & $\begin{array}{l}1,33^{*} \\
(5,17)\end{array}$ \\
\hline Közép-Dunántúl & $\begin{array}{c}1,25^{*} \\
(16,47)\end{array}$ & - & $\begin{array}{c}0,81^{*} \\
(-3,52)\end{array}$ \\
\hline
\end{tabular}

${ }^{7}$ A mintában szereplő észak-alföldi nagyvállalat miatt lehetséges, hogy a régióban alacsonyabb a készpénzes tranzakciók aránya, mint a közép-magyarországi régióban. 


\section{2. táblázat (folytatás)}

\section{A készpénzhasználatot magyarázó lineáris regressziók becsült együtthatói}

\begin{tabular}{|c|c|c|c|}
\hline Változó & Vállalatok & Kiskereskedők & Kiskereskedők (OPG) \\
\hline Nyugat-Dunántúl & $\begin{array}{c}0,86^{*} \\
(-10,77)\end{array}$ & - & $\begin{array}{l}1,55^{*} \\
(7,18)\end{array}$ \\
\hline Dél-Dunántúl & $\begin{array}{c}0,84^{*} \\
(-37,47)\end{array}$ & - & $\begin{array}{l}1,37^{*} \\
(5,00)\end{array}$ \\
\hline \multicolumn{4}{|l|}{$\begin{array}{l}\text { TEÁOR (471: nem szakosodott bolti vegyes } \\
\text { kiskereskedelem) }\end{array}$} \\
\hline $\begin{array}{l}472 \text { (szakosodott bolt, pl. hentes, pék, } \\
\text { dohány, zöldséges) }\end{array}$ & - & $\begin{array}{c}2,36^{*} \\
(12,67)\end{array}$ & $\begin{array}{c}1,14 \\
(2,54)\end{array}$ \\
\hline 473 (gépjármű-üzemanyag) & - & - & $\begin{array}{l}3,06^{*} \\
(6,33)\end{array}$ \\
\hline 474 (IT, múszaki, telekommunikáció) & - & $\begin{array}{c}0,96 \\
(-0,38) \\
\end{array}$ & $\begin{array}{c}0,56 \\
(-4,96) \\
\end{array}$ \\
\hline $\begin{array}{l}475 \text { (egyéb háztartási cikk, pl. textil, bútor, } \\
\text { villamos kisgép) }\end{array}$ & - & $\begin{array}{l}1,43^{*} \\
(4,37) \\
\end{array}$ & $\begin{array}{c}6,41^{*} \\
(23,24) \\
\end{array}$ \\
\hline $\begin{array}{l}476 \text { (kultúra, szabadidő: könyv, újság, } \\
\text { sportszer, játék) }\end{array}$ & - & $\begin{array}{c}0,88^{*} \\
(-53,37)\end{array}$ & $\begin{array}{c}0,15^{*} \\
(-19,68) \\
\end{array}$ \\
\hline 477 (ruha, cipő, gyógyszer, illatszer) & - & $\begin{array}{c}2,16^{*} \\
(10,77)\end{array}$ & $\begin{array}{c}0,97 \\
(-0,63)\end{array}$ \\
\hline 478 (piaci kiskereskedelem) & - & $\begin{array}{l}57,50 * \\
(29,74)\end{array}$ & $\begin{array}{c}8,05^{*} \\
(15,27)\end{array}$ \\
\hline $\begin{array}{l}479 \text { (nem bolti, csomagküldő, internetes } \\
\text { értékesítés) }\end{array}$ & - & $\begin{array}{c}4,29 * \\
(28,01) \\
\end{array}$ & $\begin{array}{c}6,57^{*} \\
(17,27) \\
\end{array}$ \\
\hline Van internetes értékesítés & $\begin{array}{c}0,81^{*} \\
(-12,23) \\
\end{array}$ & $\begin{array}{c}0,70 * \\
(-44,20) \\
\end{array}$ & - \\
\hline Készpénzes kifizetések darabszámának aránya & $\begin{array}{c}1,11^{*} \\
(540,81)\end{array}$ & $\begin{array}{c}1,04^{*} \\
(53,84) \\
\end{array}$ & - \\
\hline Árbevétel logaritmusa & - & - & $\begin{array}{c}0,07^{*} \\
(-52,49)\end{array}$ \\
\hline Tranzakciók száma & - & - & $\begin{array}{c}1,00 * \\
(-6,12)\end{array}$ \\
\hline Átlagos vásárlási érték logaritmusa & - & - & $\begin{array}{c}0,46^{*} \\
(-37,16)\end{array}$ \\
\hline Üzlet életideje & - & - & $\begin{array}{c}1,01^{*} \\
(19,68) \\
\end{array}$ \\
\hline Üzlet aktivitása & - & - & $\begin{array}{c}0,98 * \\
(-18,47)\end{array}$ \\
\hline Konstans & $\begin{array}{c}0,01 * \\
(-142,13) \\
\end{array}$ & $\begin{array}{l}37,06^{*} \\
(45,08) \\
\end{array}$ & $\begin{array}{c}142,22^{*} \\
(69,28) \\
\end{array}$ \\
\hline Lambda $^{8}$ & $\begin{array}{c}0,05^{*} \\
(-50,45) \\
\end{array}$ & $\begin{array}{c}0,01^{*} \\
(-12,43)\end{array}$ & $\begin{array}{c}0,02^{*} \\
(-25,08)\end{array}$ \\
\hline$R^{2}$ & 0,3 & 0,3 & 0,3 \\
\hline $\mathrm{N}$ & 113 & 187 & 33020 \\
\hline
\end{tabular}

Megjegyzés: * 95 százalékos konfidenciaszinten szignifikáns együtthatók, zárójelben a t-próbák értékei Forrás: Az MNB felmérései és a NAV onlinepénztárgép-adatai alapján végzett számítások

${ }^{8}$ A Lambda parméter (Inverz Mills ratio) minden regresszió esetén szignifikáns, ezért a kártyaelfogadókra történő szúrés szelekciós torzítást tartalmaz, emiatt a korrekció szükséges volt. 
A kérdőives adatokon készített modellekben a vállalkozások méretét a létszám-kategóriákon keresztül vettük figyelembe. Általános tendenciaként az mondható el, hogy a nagyobb vállalatoknál és kiskereskedőknél alacsonyabb szintű a bejövő készpénzes forgalom. Területi összehasonlításban a vállalatok esetében a fejlett Dunántúli régiókban (autóipar) alacsonyabb, míg az Északi és Alföldi régiókban magasabb a készpénzes tranzakciók aránya. Főtevékenység szerinti bontást csak a kiskereskedők esetében vizsgáltunk: legalacsonyabb bejövő készpénzforgalom az IT, a kulturális és szabadidős szegmensben múködő, valamint az internetes értékesítést végző kereskedők között találunk. Az internetes értékesítést külön is megvizsgáltuk egy dummy változóval, ez alapján a vállalatok körében is alacsonyabb az online is értékesítók bejövő készpénzforgalma. Szintén mutatkozott kapcsolat a kimenő készpénzes forgalommal is, ami arra utalhat, hogy egyes vállalkozások azért preferálják a készpénzes vásárlások elfogadását, mert kimenő fizetéseiket is ilyen módon kell teljesíteniük.

Az onlinepénztárgép-adatokon készített döntési fához hasonlóan a lineáris modellben is az látható, hogy a rendelkezésre álló magyarázó változók közül az árbevétel logaritmusa és az átlagos vásárlási érték a legfontosabb magyarázó változók és negatív kapcsolatban állnak a készpénzaránnyal. A területi változók itt szignifikáns magyarázó erővel rendelkeznek, a régiók esetében látható, hogy a Budapest, Közép-Magyarország referenciaszinthez képest csak Közép-Dunántúlon alacsonyabb, mindenhol másutt magasabb a készpénzhasználati arány. Ez összefüggésben lehet a Kajdi - Nemecskó (2020) által a kártyahasználatra vonatkozóan feltárt regionális eltérésekkel is. A tevékenységi körök esetében a bolti vegyes kiskereskedők referenciakörhöz képest az adózó főtevékenysége alapján, az IT, műszaki és kultúra szabadidő esetében alacsonyabb, míg a többi tevékenységi körű üzletek esetében közel azonos vagy magasabb a készpénzhasználat. A TEÁOR-kód alapján előfordultak itt is eltérések, amelyeknek okai a korábban említett kérdőíves kis mintaelemszám lehet, illetve az eredmények értelmezésénél azt is figyelembe kell venni, hogy az egységek tényleges tevékenysége eltérhet az adózóhoz bejelentett fő tevékenységétôl.

\section{Pénzügyi tudatosság}

A fizetési módok közötti választást befolyásolhatja a pénzügyi tudatosság, ezen belül az egyes fizetési módokhoz kapcsolódó költségek. A vállalatok és kiskereskedők kérdőíves felméréseinél az ezekre vonatkozó kérdésekre adott válaszokat ebben a fejezetben mutatjuk be. Ezen információk legnagyobb részét a pénzforgalmi költségekre vonatkozó adatok jelentik, vagyis az, hogy a készpénzes és elektronikus fizetési módok biztosítása mekkora díjterhekkel jár. Ezen túlmenően több kérdés vonatkozott a jövőbeli fejlesztési tervekre is, elsősorban az azonnali fizetés hazai bevezetésére. 


\subsection{Készpénzhasználat}

A nap végi készpénzállomány a vállalatok esetében a mérettel arányosan növekszik, míg a kiskereskedők esetében nem látszik ilyen egyértelmű tendencia. A forgalmi adatokkal összhangban a kisebb vállalatoknál több a készpénzes tranzakció, míg a nagyobb vállalatoknál szinte minimális a készpénzes múveletek száma. A kisebb vállalatokra főleg a készpénzfelvétel, míg a nagyobbakra a készpénzbefizetés jellemző. Ez arra utal, hogy a kisebb vállalatoknak nagyobb a készpénzigénye, akár az átutalások útján érkezett bevételt is felveszik készpénzben annak érdekében, hogy a készpénzes kiadásaikat fedezni tudják. Ahogy azt a forgalmi adatok elemzésénél is bemutattuk, a nagyobb vállalatok esetében a készpénzes tranzakciók aránya alacsony, így esetükben az a jellemzőbb, hogy a beérkezett készpénzt befizetik a bankszámlákra, amivel a nagyobb volumenú internetes forgalmukat is támogatják. A kiskereskedők esetében a létszám növekedésével fennálló egyértelmű kapcsolatot nem lehetett azonosítani. Ugyanakkor elmondható a kiskereskedői adatok alapján, hogy a készpénzbefizetések értéke általában meghaladta a felvételekét. Ennek oka feltehetően az lehet, hogy a kisebb kereskedők bejövő forgalmánál egyébként is jellemzőbb a készpénz, így készpénzszükségletüket ilyen módon tudják fedezni.

A munkavállalók bérét a vállalatok jellemzően átutalással fizetik. A kisvállalatoknál a készpénzes munkabérfizetés 35 százalék, míg a nagyobb vállalatoknál ez egyáltalán nem jellemző. Ahogy bemutattuk, a kisebb vállalatok pénzforgalmának jelentős része készpénzben történik (2., 3., 4. ábra), ezzel összhangban van, hogy a munkabérek egy részét is készpénzben fizetik ki. Azon vállalatok közül, amelyek nem csak átutalással fizetnek munkabért, 30 százalék jelezte, hogy a drága banki díjak miatt nem az átutalásos bérfizetést választja. A vállalatok közel 50 százalékánál a bérek kifizetése azért készpénzben történik, mert az alkalmazottak ezt a bérfizetést preferálják. Vélhetően az elektronikus fizetések terjedésével ez az arány visszaszorulhat, mivel jelenleg még több elfogadónál nincs lehetőség elektronikus fizetésre. Több térségben nincs kellően fejlett elfogadói hálózat, ezért nincs lehetőség elektronikus fizetésre sem (Kajdi - Nemecskó 2020). Az azonnali fizetés bevezetésével a kereskedők széles rétegének nyílik lehetősége elektronikus fizetés elfogadására, ezzel csökkenhet a készpénzes fizetések aránya. A készpénzes bérfizetést alkalmazó kiskereskedők esetében nem volt azonosítható egyértelmű mögöttes ok, a felsorolt három tényezőt (banki költségek, készpénzes bevételek, alkalmazottak preferenciája) egységesen körülbelül a válaszadók 60 százaléka jelölte meg. Ez azt jelzi, hogy mindegyik ok nagyban hozzájárul a készpénzes bérfizetésekhez.

\subsection{Bankválasztás és banki költségek}

A vállalkozások több szempont alapján döntenek a számlavezető bankjukról, ezeket kvalitatív jellegű kérdésekkel mértük fel. A vállalatoknál a legjelentősebb szempontot a banki költségek jelentik, 30 százalék választott ez alapján bankot. A személyes, bankfióki ügyintézés a vállalatok 20 százalékának, az ATM-elérhetőség 10 
százalékuknak volt fontos, 20 százalék pedig a lakossági számláját vezető bankot választotta. A kedvező hitelfeltételek, a bankkártya-elfogadói szolgáltatás nyújtása és a mobilbanki alkalmazás a vállalatok 5 százalékának volt fontos.

A kiskereskedők esetében a válaszadók 32 százaléka választott a költségek alapján, a legfontosabb tényező azonban ebben a szegmensben a személyes ügyintézés lehetősége: a kereskedők 42 százalékának fontos, hogy legyen a közelben bankfiók, 28 százalékuknál az ATM elérhetősége is lényeges. A már meglévő banki kapcsolatok fontossága a vállalatokhoz hasonlóan alakult: míg viszonylag jelentős (egyharmad) volt azon kiskereskedők aránya, amelyek a lakossági számlájukat vezető bankot választották üzleti ügyeik intézéséhez, a meglévő hitelek szerepe csekély (8 százalék) volt. Pozitívnak tekinthető, hogy 16 százalék jelölte azt, hogy fontos, hogy legyen banki mobilalkalmazás.

\subsection{Azonnali fizetés}

Mivel az adatfelvételek az azonnali fizetés 2020. március 2-i magyarországi bevezetése előtt készültek, ezért lehetőség nyílt a hazai vállalkozások azonnali fizetéssel kapcsolatos előzetes ismereteit is vizsgálni. A kiskereskedelmi szektorban a válaszadók több mint fele, a vállalatoknál kétharmada hallott az azonnali fizetésről még a szolgáltatás indulása előtt. A kiskereskedők harmada, a vállalatok 65 százaléka hallott már arról, hogy a központi infrastruktúrához nemcsak bankokon, de nem banki szolgáltatókon vagy akár közvetlenül is lehet csatlakozni. Ez a fajta pénzügyi tudatosság a későbbiekben erősítheti a szolgáltatók közötti versenyt is.

Az azonnali fizetések kereskedői elfogadásánál 68 százalék tette első helyre az árazási szempontokat, azaz akkor fontolnák meg a bevezetést, ha annak díjai kedvezőbbek lennének a jelenlegi kártyaelfogadási feltételeknél. A vásárlások ellenértékének azonnali beérkezését már csak jóval kevesebben (18 százalék) jelölték első helyen, ugyanakkor az árazás után jellemzően ez volt a második legfontosabb tényező. A vásárlói szempontokat („legyen legalább olyan kényelmes, mint a kártyás fizetés”) és azt, hogy a mobilfizetések, illetve a hozzá kapcsolható különböző kedvezményprogramok révén még jobban megismerhetik vevőik vásárlási szokásait csak a kereskedők alacsony hányada tartotta fontosnak. A nem kiskereskedelmi vállalatok esetében nem volt lényegi eltérés a felsorolt szempontok priorizálásánál.

\section{Következtetések}

A jelen tanulmányban a magyarországi kiskereskedők és vállalatok fizetési szokásait vizsgáltuk. Ehhez két kérdőíves felmérés adatait használtuk fel, és további adminisztrativ adatbázisokat ( $p l$. onlinepénztárgép-adatok) is vizsgáltunk a még pontosabb összefüggések feltárása érdekében. A két vizsgált szegmens (kiskereskedői és vállalati) között lényegi eltérések látszanak: míg a kiskereskedő́k pénzforgalma sokkal inkább készpénzintenzív és a bankkártyás fizetés mellett szinte nem is alkalmaznak 
más elektronikus fizetési módot, addig a vállalatok esetében számottevő az átutalások szerepe, és kisebb a készpénzhasználat aránya.

A pénzforgalomban jelentős eltérések láthatók a vállalatok létszáma alapján képzett méretkategóriák szerint, a kisebb vállalkozásoknál jóval nagyobb a készpénz szerepe. A kisebb vállalatokat, illetve a teljes kiskereskedői szegmenst tekintve is viszonylag magas még azoknak a vállalkozásoknak az aránya, amelyek túlnyomórészt készpénzben fizetik a béreket. Ennek vélhetően az is oka, hogy a bevételeik nagy része is készpénzben keletkezik.

A kártyaelfogadást befolyásoló tényezők közül a méret a leginkább meghatározó, emellett eredményeink alapján negatívan befolyásolják a készpénzes bérfizetések is, amivel kapcsolatban felmerül a kérdés: egyszerűen a rejtett gazdaság velejárójáról van szó, vagy a korábbi megszokások, az alkalmazottak preferenciái is hatással lehetnek erre. Elemzésünk alapján pozitív kapcsolat mutatható ki az átlagos vásárlási érték és a kártyaelfogadás között is, ami összhangban van a korábbi eredményekkel, miszerint a nagyobb értékű vásárlások esetében gyakoribb a kártyás fizetés. Ebből következhet a közvetett hatás, hogy jobban el is várják azokban a boltokban az elektronikus fizetési alternatíva nyújtását, ahol a nagyobb összegű fizetések jellemzőbbek, ezzel kikényszerítve annak biztosítását. Az életidő ugyan erősen szignifikáns változó, de kis mértékben negatívan hat az elfogadásra. Ennek oka az lehet, hogy a később nyitott boltok nagyobb valószínűséggel elfogadók. A kártyát el nem fogadók indoklásait áttekintve a kérdőívre válaszolók szerint a vevők nem igénylik a kártyás fizetési lehetőséget, ugyanakkor ezt egyrészt meglehetősen nehéz vizsgálni, másrészt kirajzolódik az egymásra ható láncolat: a vevők nem igénylik (azaz nem jelzik, hogy elektronikusan fizetnének), emiatt nincs mindenhol POS-terminál, illetve a befolyó nagymennyiségű készpénz és az elektronikus fizetési lehetőségek hiánya miatt az alkalmazottak is ilyen módon kapják a bérüket. Emellett a magas költség volt a kártyák nem elfogadásának másik fő indoka.

Ez alapján tehát elsősorban a mikro- és kisvállalkozások szegmensét érdemes célozni közpolitikai intézkedésekkel, ha az elektronikus fizetési módok szélesebb körű használatát szeretnénk elérni. Mivel ebben a csoportban lényeges a költségtényező, ezért a korábbi elfogadási módokhoz képest lényegesen olcsóbban kialakítható azonnali fizetésnek ezen a téren is fontos szerep juthat.

Az azonnali fizetés széleskörű elterjedésével és a 2021-től az online pénztárgépet használó kereskedők elektronikus elfogadásra történő kötelezésével vélhetően tovább nő majd az elektronikus fizetést elfogadó üzletek aránya. Megjelenhetnek például az átutaláson alapuló fizetési megoldások a kiskereskedelemben is, így ez az elemzés jó pillanatkép lehet az azonnali fizetés és a kötelező elfogadás bevezetése előtti időszakról, amihez később viszonyítani lehet a fejlődés következő időszakát. Mivel számos felmerülő piaci problémára jelenthet megoldást az azonnali fizetés 
elterjedése, ezért biztató, hogy mind a megkérdezett kiskereskedők, mind a vállalatok túlnyomó többsége hallott az azonnali fizetésről, ami keresleti oldalról erősítheti a jövőbeli szolgáltatások fejlesztését.

\section{Felhasznált irodalom}

Bartha Lajos - Luspay Miklós - Varga Lóránt (2017): Pénzforgalom és pénzügyi infrastruktúrák. In: Vonnák Balázs (szerk.): Modern jegybanki gyakorlat. Magyar Nemzeti Bank, pp. 287-360.

Belházyné Illés Ágnes - Végső Tamás - Bódi-Schubert Anikó (2018): A magyarországi mikro-, kis-és középvállalkozások fizetési szokásainak elemzése - fókuszban a készpénzhasználat. Hitelintézeti Szemle, 17(4): 53-94. http://doi.org/10.25201/HSZ.17.4.5394

Bódi-Schubert Anikó (2014): Bizalom(hiány) és fizetési magatartás a kis- és középvállalatok üzleti kapcsolataiban. MNB-tanulmányok 110, Magyar Nemzeti Bank. https://www.mnb. hu/letoltes/mt110-vegleges.pdf

Bounie, D. - François, A. - Van Hove, L. (2017): Consumer Payment Preferences, Network Externalities, and Merchant Card Acceptance: An Empirical Investigation. Review of Industrial Organization, 51(3): 257-290. https://doi.org/10.1007/s11151-016-9543-y

Dahlberg, T. - Öörni, A. (2008): Understanding Changes in Consumer Payment Habits - Do Mobile Payments Attract Consumers? Sprouts, Working Papers on Information Systems. https://www.academia.edu/5822166/Understanding_Changes_in_Consumer_Payment_ Habits_Do_Mobile_Payments_Attract_Consumers. Letöltés ideje: 2021. január 23.

The Danish Payments Council (2019): Business-to-business payments entailed social costs of kr. 4.2 billion. Series: Costs of payments in Denmark 2016. https://www.nationalbanken. dk/en/publications/Documents/2019/02/BR_Business-to-business\%20payments\%20 in\%20Denmark\%202016.pdf. Letöltés ideje: 2021. január 19.

ECB (2020): Study on the payment attitudes of consumers in the euro area (SPACE). European Central Bank, December. https://www.ecb.europa.eu/pub/pdf/other/ecb. spacereport202012 bb2038bbb6.en.pdf

Górka, J. (2012): Payment Behaviour in Poland - The Benefits and Costs of Cash, Cards and Other Non-Cash Payment Instruments. https://www.bundesbank.de/resource/ blob/635066/b8afafb1655f5d7d89332d836367454a/mL/2012-02-27-eltville-09-gorkapaper-data.pdf. Letöltés ideje: 2021. március 11.

Gresvik, O. - Haare, H. (2008): Payment habits at point of sale. Norges Bank, Staff Memo No. 6. https://www.norges-bank.no/globalassets/upload/publikasjoner/staff-memo/2008/ staff_memo_2008_06.pdf?v=03/09/2017122428\&ft=.pdf 
Harasim, J. - Klimontowicz, M. (2013): Payment Habits as a Determinant of Retail Payment Innovations Diffusion: the Case of Poland. Journal of Innovation Management, 1(2): 86102. https://doi.org/10.24840/2183-0606_001.002_0007

Ilyés Tamás - Varga Lóránt (2015): Mutasd, mivel fizetsz, megmondom, ki vagy A pénzforgalmi szokásokat befolyásoló szociodemográfiai tényezők. Hitelintézeti Szemle, 14(2): 26-61. https://www.mnb.hu/letoltes/2-ilyes-varga.pdf

Ilyés Tamás - Varga Lóránt (2018): A kereskedők fizetésikártya-elfogadása Magyarországon az online pénztárgépek adatai alapján. Hitelintézeti Szemle, 17(1): 83-109. http://doi. org/10.25201/HSZ.17.1.83109

Jonker, N. - Hernandez, L. - de Vree, R. - Zwaan, P. (2018): From cash to cards: how debit card payments overtook cash in the Netherlands. De Nederlandsche Bank - Dutch Payments Association, Occasional Studies Volume 16-1. https://www.dnb.nl/media/ kx1akmnb/201802_nr_1_-2018-_from_cash_to_cards_how_debit_card_payments_ overtook_cash_in_the_netherlands.pdf

Kajdi László - Nemecskó István (2020): A kártyás fizetési mód területi jellemzői Magyarországon. Hitelintézeti Szemle, 19(1): 65-89. http://doi.org/10.25201/ HSZ.19.1.6589

Kosse, A. - Chen, H. - Felt, M. - Jiongo, V.D. - Nield, K. - Welte, A. (2017): The Costs of Point-of-Sale Payments in Canada. Bank of Canada, Staff Discussion Paper 2017-4. https:// www.bankofcanada.ca/wp-content/uploads/2017/03/sdp2017-4.pdf

Leinonen, H. (2008): Payment habits and trends in the changing e-landscape 2010+. Bank of Finland Expository Studies A:111. https://www.finextra.com/finextra-downloads/ featuredocs/a111.pdf

Looke, Y.J. (2007): Determinants of Merchant Participation in Credit Card Payment Schemes. Review of Network Economics, 6(4):1-22. https://doi.org/10.2202/1446-9022.1130

Takács Kristóf (2011): A magyar háztartások fizetési szokásai. MNB-tanulmányok 98, Magyar Nemzeti Bank. https://www.mnb.hu/letoltes/mt98.pdf

Turján Anikó - Divéki Éva - Keszy-Harmath Zoltánné - Kóczán Gergely - Takács Kristóf (2011): Semmi sincs ingyen: A föbb magyar fizetési módok társadalmi költségének felmérése. MNB-tanulmányok 93, Magyar Nemzeti Bank. https://www.mnb.hu/letoltes/mt93.pdf 